\title{
Landholders' Involvement in the Compulsory Acquisition of Land and Compensation Process in Bauchi, Nigeria
}

\section{Muhammad Usman Adekunle ${ }^{1}$, Maryam Salihu Muhammad ${ }^{1}$, Mathew Oyewole Oluwole ${ }^{2}$, Hadiza Tijjani Bello ${ }^{1}$, Ibrahim Idris ${ }^{1}$}

\author{
${ }^{1}$ Abubakar Tafawa Balewa University \\ Tawafa Belewa Way, P. M. B. 0248, Bauchi, 740272, Nigeria \\ 2 Obafemi Awolowo University \\ P.M.B. 13, Osun, 220282, Nigeria
}

DOI: $10.22178 /$ pos.50-2

JEL Classification: Q15

Received 30.08.2019

Accepted 28.09.2019

Published online 30.09.2019

Corresponding Author:

Muhammad Usman Adekunle

babaucy@gmail.com

(C) 2019 The Authors. This article

is licensed under a Creative Commons

Attribution 4.0 License @) (1)

\begin{abstract}
This study aims to assess landholder's involvement in the compulsory acquisition of land on their satisfaction with the compensation process in Bauchi, Nigeria, to identify areas of weakness in the process and propose areas of improvement. The study adopted the use of a quantitative approach and data were collected through a questionnaire survey from 327 landholders affected by the compulsory acquisition and compensation exercise by the Bauchi State Government. The data collected were subjected to descriptive with mean ranking, frequency distribution. The study revealed that before the process of compulsory acquisition landholders were very well involved, during the process of compulsory acquisition they were also involved but at the compensation process, they were not involved at all. It recommended that Landholders should be involved not only in the process of compulsory acquisition but they should be involved in the process of compensation as it will minimize resistance to compulsory.
\end{abstract}

Keywords: landholders; involvement; compulsory acquisition; compensation process.

\section{INTRODUCTION}

Compulsory land acquisition in common law is an inherent power of government to seize private interest in land and landed property, expropriate property without the willingness/consent of the affected landholders [15]. It is also referred to as the rights of government to take possession of property it does not own for overriding public interest [16]. Compulsory land acquisition has different terms in relation to different countries, in the USA it is referred to as eminent domain, while it is being regarded as compulsory acquisition in Austria or expropriation in South Africa and the United Kingdom it is called compulsory purchase.

In India compulsory land acquisition means acquiring land for some public purpose by government or its agencies authorized by the law. The land is then acquired from affected landholders after payment of a fixed compensation has been made in lieu to the losses incurred by the landholder's [8]. The property compulsorily acquired is usually taken for government use or by delegation to third parties who will in order utilize it for public use in some cases for economic development [8].In Nigeria, compulsory land acquisition is backed by section 28 of the Land Use Act of 1978 and the Land Use Act Cap L5, Laws of Federal Republic of Nigeria (LFN) 2004, which is the principal legislation guiding compulsory acquisition of land. It provides compulsory acquisition of land by government for overriding public interest.

Some countries laws provide a list that falls within the definition of overriding public interest [13]. Some of these purposes include the development of infrastructures such as roads, canals, airports, housing, dams, and cemeteries etcetera [6]. Compulsory land acquisition is no doubt a necessary government power to make land available for the provision of social amenities. 
However it has attracted numerous controversies in practice. This has resulted to the displacement of a whole/part of the community, affects people cohesion, livelihood and their general way of life.

\section{LITERATURE REVIEW}

Most legislation involved in compulsory acquisition and compensation all over the world is geared towards making land available to governments for the provision of social infrastructure to its citizens with adequate compensation to be paid to disposed landholder's [5]. The procedures and method employed by most governments are seen as compatible among countries around the globe though it varies in practice base on its implementation.

Compulsory land acquisition is the process which many governments use to obtain land/landed property without the willingness of the disposed landholder's for the provision of infrastructure such as roads, hospitals, schools, airports, seaports, etc. for its citizens this is usually done for overriding public interest [7]. Each country or region of the world has legislation which governs the process of land acquisition and the method of valuation for compensation.

Compulsory land acquisition is the most challenging aspect in land management as it affects both the government and the governed, thus the displaced landholders are usually unpleased with the process but are entitled to a fair, just and adequate compensation to minimize their loss [5]. Also [7] asserted that compulsory land acquisition is a vital tool of government to acquire land for the development of its citizens, compulsory land acquisition in some countries is done through other means such as by voluntary agreement and even resettlement of the affected landholder's. Where the purpose for compulsorily acquiring people's land is done with the motive of developing infrastructure such as hospitals, schools, roads, etc., is usually accepted with less or no resistant, though accompanied by the payment of just compensation and/or resettlements of the affected landholder's.

However, if the land were compulsorily acquired by the government for private motive/undertaking such as for personal development by those in government and or its associates, then there is bound to be some forms of resistance by the landholders [8]. Author [10] opined that where landholders are being dispossessed against their will and the amount paid as compensation is unjust or inadequate when compared with their loss, this may result in conflicts between landholders, governments and even resistance against the agency involved in the development of such land.

\section{Principles of Compulsory Acquisition and Compensation}

There are some guiding principles the guides compulsory acquisition/compensation of land/landed properties from intending or already disposed of landholder's which is the principle of "equity and equivalence" [5]. This principle is the fulcrum for compensation and its application cannot be overemphasized in determining compensation. The principle states that affected landholders and occupants should not only be involved but should be neither enriched nor impoverished as a result of the compulsory acquisition of their land/landed properties. The finding principle for ensuring equity and equivalence

Equivalence: affected landholders by compulsory acquisition should receive compensation that is no more or less than the loss incurred as a result of the dispossession. Appropriate measures should be used to ensure that the affected landholders and particularly the vulnerable (locals) are not disadvantaged.

Balance of interest: the procedure should ensure the security of the rights of people who were dispossessed of the ownership rights of their land/landed properties while ensuring that the public interest is not jeopardized.

Flexibility: the law should be specific enough to provide clear guidelines, but also flexible enough to allow for the determination of appropriate equivalent compensation. Compensation should be able to address both Defacto and Dejura's rights equitably following the principle of equivalence. This means that compensation should take into consideration the legal rights of the dispossessed landholders as well as the rights of occupants who are not recognizable legal rights.

Fairness and transparency: the negotiating powers of government and landholders should be as equal as possible. Negotiation should be anchored on an open basis of exchange of information and the legislation should ensure a fair 
process for determining the value and compensation payable.

Fair and adequate: compensation of compulsory acquisition of land/landed property should be fair and adequate, it should restore dispossessed landholder's to a state where they are neither better nor worse off at the end of the revocation exercise [12]. He further stated that the methods of assessment used by the government to determine compensation must sustain the principle of equity under which landowner is to be left a whole in terms of naira and that the requirement for the payment of compensation on acquired lands includes the right to compensation and social equity.

However, a study by [1] stated that the Nigerian compensation practice does not comply with the above-stated principles thus. The inequity embedded in the Nigerian compensation practice.

\section{METHODOLOGY}

For the purpose of this research, the nonprobabilistic sampling technique using snowball will be adopted. Snowball sampling is especially useful when a researcher is trying to identify samples of a population that are difficult to locate. The use of scale was adopted because, according to [9], it ensures that questions or statements are posed in a fair and balanced way especially in measuring the strength of attitude and perception. Similarly, limiting the scale points at 5 points was considered appropriate because it gives respondents a reasonable range of options to choose from. The questionnaire for this research was self-administered.

The research will be analyzed using the mean ranking for the variables, in order to achieve this, descriptive test will be carried out to ensure the mean will be entered correctly; for objective iv regression analysis will be used to establish the effect between the research constructs, using the SPSS version 21 software package to carry out the analysis.

This study adapted the mean score decision interval based on the works of [14] from which the following interval decisions were deduced. (1$1.80)=$ Very low $(1.81-2.60)=\operatorname{Low}(2.61-3.40)=$ Moderate (3.41-4.20) $=$ High (4.21-5.0) Very high.

\section{RESULTS AND DISCUSSION}

Reliability is a measure of how the scale is free from random error. Internal consistency measures the degree to which measurement scale responses are consistent across constructs [2, 3] stated that the most common measure of reliability is the Cronbach's alpha. The recommended minimum value of Cronbach's alpha for scales is $0.7[11,4]$. The reliability of the measurement scale was assessed using the recommended minimum of Cronbach's alpha coefficient of 0.7.

The test revealed that both awareness and involvement have good internal consistency with Cronbach's Alpha of 0.79 each while satisfaction has an excellent internal consistency with Cronbach's Alpha of 0.87 (Table 1)

Table 1 - Cronbach's Alpha Value of questionnaire constructs

\begin{tabular}{|l|l|c|c|l|}
\hline No & Variables & $\begin{array}{c}\text { Item Statistics } \\
\text { / No. of } \\
\text { construct }\end{array}$ & $\begin{array}{c}\text { Cronbach's } \\
\text { Alpha } \\
\text { Value }\end{array}$ & $\begin{array}{c}\text { Reliability } \\
\text { status }\end{array}$ \\
\hline 1 & Awareness & 10 & 0.79 & Acceptable \\
\hline 2 & Involvement & 9 & 0.79 & Acceptable \\
\hline 3 & Satisfaction & 14 & 0.87 & Good \\
\hline
\end{tabular}

Similarly, the aim of the research to determining Landholders' involvement in the compulsory acquisition of land and compensation process in the study area was analysis using Likert scale level 1 - 5 stressing on various variables of landholders' involvement which are found in related literature. The scale questions used are: Not involved at all $=1$, Partially involved $=2$, Neutral $=$ 3 , Involved $=4$ and Very well involved $=5$. Data regarding this were collected and presented in table 2 below.

As revealed in table 3 above landholders were highly involved in process of compulsory land acquisition and the entire process of land acquisition with mean score of 4.7593 and 4.6407 ranked 1st and 2nd respectively, neutral in the process of compensation for the compulsorily acquired land with mean score of 2.1556 ranked 3rd, landholders were not involved at all in receiving of award for compensation, in receiving of compensation money, In signing of statement for acceptance/rejection of compensation award, in the computation of land and economic trees during actual valuation, in the submission of claims for compensation for land acquired in the actual valuation of your assets prior to compensation with mean score of 1.7889, 1.6741, $1.6704,1.2407,1.2370$ and 1.1963 ranked 4th, 5th, 6th, 7th, 8th, 9th, and 10th respectively. 
Table 2 - Landholders Involvement in Compulsory Acquisition of Land and Compensation Process

\begin{tabular}{|l|r|r|r|r|}
\hline \multicolumn{1}{|c|}{ Variables } & \multicolumn{1}{|c|}{ Mean } & \multicolumn{1}{c|}{ Std. Deviation } & \multicolumn{1}{c|}{ Ranking } & Remark \\
\hline $\begin{array}{l}\text { Involvement in the process of com- } \\
\text { pulsory land acquisition }\end{array}$ & 4.7593 & .42833 & Very High \\
\hline Involvement in the entire process & 4.6407 & .48067 & 2nd & Very High \\
\hline $\begin{array}{l}\text { Process of compensation for the } \\
\text { compulsory acquired land }\end{array}$ & 2.1556 & .47290 & Low \\
\hline $\begin{array}{l}\text { Involvement in receiving of award } \\
\text { for compensation }\end{array}$ & 1.7889 & 1.35648 & 5th & Very Low \\
\hline $\begin{array}{l}\text { Involvement in receiving of com- } \\
\text { pensation money }\end{array}$ & 1.6741 & 1.28375 & 6th & Very Low \\
\hline $\begin{array}{l}\text { In signing for acceptance/rejection } \\
\text { of compensation award }\end{array}$ & 1.6704 & 1.28425 & 7th & Very Low \\
\hline $\begin{array}{l}\text { Involvement in the computation of } \\
\text { land and economic trees }\end{array}$ & 1.2407 & .42833 & 8th & Very Low \\
\hline $\begin{array}{l}\text { The submission claims for compen- } \\
\text { sation for land }\end{array}$ & 1.2370 & .42605 & 9th & Very Low \\
\hline $\begin{array}{l}\text { The actual valuation of your assets } \\
\text { prior to compensation }\end{array}$ & 1.1963 & .39793 & & \\
\hline
\end{tabular}

The above result revealed the level of landholder's involvement in the compulsory acquisition of land and compensation process is very high, low and very low respectively.

\section{CONCLUSION}

This study aimed to assess landholder's awareness and involvement in the compulsory acquisition of land on their satisfaction with the com- pensation process in Bauchi to identify areas of weaknesses in the process.

The study came at a time when the government compulsorily acquires land for overriding public interest to provide infrastructural facilities.

Likewise, the findings from the survey carried out indicated that landholders were very well involved in the process of compulsory acquisition but dissatisfied with the compensation process.

\section{REFERENCES}

1. Akujuru, V. A., \& Ruddock, L. (2014). The Determination of Compensation Payable in the Niger Delta for Compulsory. Journal of Sustainable Development in Africa, 16(2), 1-13.

2. Awang, Z. (2014). Research methodology and data analysis (2nd ed.). Selangor: UiTM press.

3. Creswell, J. W. (2014). Research design: qualitative, quantitative and mixed method approaches (4th ed.) Thousand Oaks: Sage Publications.

4. DeVellis, R. F. (2016). Scale development: theory and applications (4th ed.). California: Sage publications.

5. Food and Agricultural Organization. (2009). Good governance in land administration. Retrieved from http://www.fao.org/3/a-ak375e.pdf

6. Gyasi, V. L. (2016). Compulsory Land Acquisition and Payment of Compensation in Gana (Master's thesis). Retrieved from http://ir.knust.edu.gh/bitstream/123456789/10401/1/vida\%27s_thesis\%20new.\%20\%2002 44855230.pdf

7. Kakulu, I. I., Byrne, P. \& Viitanen, K. (2009). Phenomenological Research in Compulsory Land Acquisition and Compensation. Retrieved from 
https://www.researchgate.net/publication/237469342_Phenomenological_Research_in_Compu lsory_Land_Acquisition_and_Compensation

8. Larbi, W. O. (2008). Compulsory Land Acquisition and Compensation in Ghana: Searching for Alternative Policies and Strategies. Retrieved from https://www.researchgate.net/publication/252919695_Compulsory_Land_Acquisition_and_Co mpensation_in_Ghana_Searching_for_Alternative_Policies_and_Strategies

9. Mathers, N., Fox, N, \& Hunn, A. (2009). Survey and questionnaires. Nottingham: The NIHR RDS for East Midlands.

10. Ndjovu, C. (2016). Understanding causes of dissatisfactions among compensated landowners in expropriation programs in Tanzania. International Journal of Scientific and Technology Research 5(1), 1-7.

11. Nunnally, J. O. (1978). Psychometric analysis. New York: McGraw-Hill.

12. Olusegun, K. (2009). Principles and Practice of Property Valuation in Nigeria. Ibadan: Atlantis Book.

13. Onuoha, R. A. (2016). An exposition on the concept and legality of compulsory. Sacha Journal of Policy and Strategic Studies, 5(1), 1-14.

14. Ramli, L., Mohamed, Z., Abdullahi, A. M., Jaafar, H. I., \& Lazim, I. M. (2017). Control strategies for crane systems: A comprehensive review. Mechanical Systems and Signal Processing, 95, 1-23. doi: 10.1016/j.ymssp.2017.03.015

15. Udoekanem, N. B., Adoga, D. O., \& Onwumere, V. O. (2014). Land Ownership in Nigeria : Historical Development, Current Issues and Future Expectations. Journal of Environment and Earth Science, 4(21), 182-189.

16. Yue, L. (2009, March). Analyzing effects of Land Use Rights on Urbanization in P. R. China. Retrieved from https://webapps.itc.utwente.nl/librarywww/papers_2009/msc/gimla/yuelv.pdf 